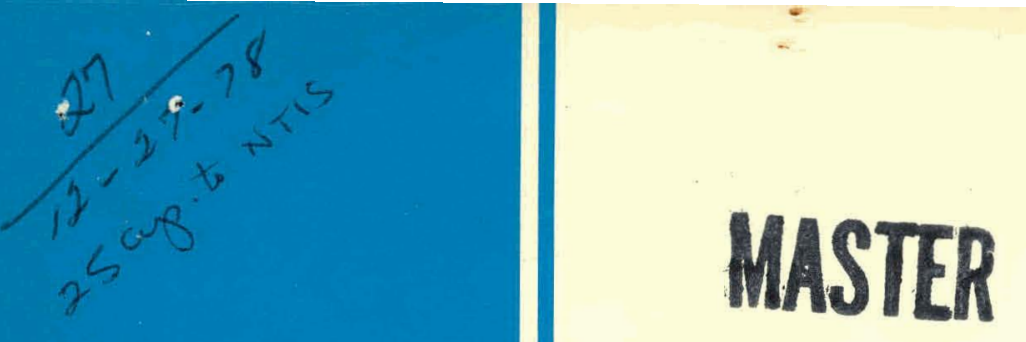

\title{
Cooling Tower Drift Studies at the Paducah, Kentucky Gaseous Diffusion Plant
}

\author{
Fred G. Taylor \\ Steven R. Hanna \\ Patricia D. Parr
}
ENVIRONMENTAL SCIENCES DIVISION
Publication No. 1275




\section{DISCLAIMER}

This report was prepared as an account of work sponsored by an agency of the United States Government. Neither the United States Government nor any agency Thereof, nor any of their employees, makes any warranty, express or implied, or assumes any legal liability or responsibility for the accuracy, completeness, or usefulness of any information, apparatus, product, or process disclosed, or represents that its use would not infringe privately owned rights. Reference herein to any specific commercial product, process, or service by trade name, trademark, manufacturer, or otherwise does not necessarily constitute or imply its endorsement, recommendation, or favoring by the United States Government or any agency thereof. The views and opinions of authors expressed herein do not necessarily state or reflect those of the United States Government or any agency thereof. 


\section{DISCLAIMER}

Portions of this document may be illegible in electronic image products. Images are produced from the best available original document. 
Printed in the United States of America. Available from National Technical Information Service

U.S. Department of Commerce

5285 Port Royal Road, Springfield, Virginia 22161

Price: Printed Copy $\$ 4.50$; Microfiche $\$ 3.00$

This report was prepared as an account of work sponsored by an agency of the United States Government. Neither the United States Government nor any agency thereof, nor any of their employees, contractors, subcontractors, or their employees, makes any warranty, express or implied, nor assumes any legal liability or responsibility for any third party's use or the results of such use of any information, apparatus, product or process disclosed in this report, nor represents that its use by such third party would not infringe privately owned rights. 
Contract No. W-7405-eng-26

\section{COOLING TOWER DRIFT STUDIES AT THE PADUCAH, KENTUCKY GASEOUS DIFFUSION PLANT}

Fred G. Taylor, Steven R. Hanna, 1 and Patricia D. Parr

ENVIRONMENTAL SCIENCES DIVISION

Publication No. 1275
This report was prepared as an account of work sponsored by the United States Government. Neither the United States nor the United States Department of Energy, nor any of their employees, nor any of their contractors, subcontractors, or their employees, makes any warranty, express or implied, or assumes any legal liability or responsibility for the accuracy, completeness or usefulness of any information, apparatus, product or process disclosed, or represents that its use would not infringe privately owned rights.

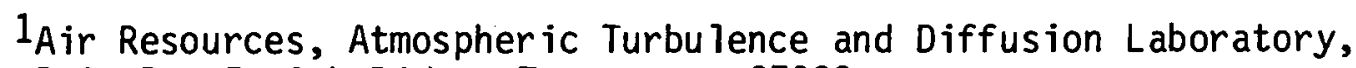
P.0. Box E, Oak Ridge, Tennessee 37830

Date Published: December 1978

NOTICE This document contains information of a preliminary nature. It is subject to revision or correction and therefore does not represent a final report.

OAK RIDGE NATIONAL LABORATORY

Oak Ridge, Tennessee 37830

operated by

UNION CARBIDE CORPORATION

for the

DEPARTMENT OF ENERGY 


\section{THIS PAGE}

\section{WAS INTENTIONALLY}

LEFT BLANK 


\section{ACKNOWLEDGMENT}

R. C. Baker and M. C. Conrad (Paducah) are gratefully acknowledged for their assistance and cooperation in coordinating access to the environs of the Paducah Gaseous Diffusion Plant. D. L. Ashburn (Paducah) and J. D. Story (ORNL) provided valuable assistance in the collection of field samples. Analytical capabilities were provided by R. E. Simmons (Paducah), F. L. Ball and N. M. Ferguson (ORNL). 
THIS PAGE

\section{WAS INTENTIONALLY LEFT BLANK}


ABSTRACT

TAYLOR, F. G., S. R. HANNA, and P. D. Parr. 1978. Cooling tower drift studies at the Paducah, Kentucky Gaseous Diffusion Plant. ORNL/TM-6131. Oak Ridge National Laboratory, Oak Ridge, Tennessee. $46 \mathrm{pp}$.

The transfer and fate of chromium from cooling tower drift to terrestrial ecosystems were quantified at the Department of Energy's uranium enrichment facility at Paducah, Kentucky. Chromium concentrations in plant materials (fescue grass) decreased with increasing distance from the cooling tower, ranging from $251 \pm 19$ ppm at 15 meters to $0.52 \pm 0.07 \mathrm{ppm}$ at 1500 meters. The site of drift contamination, size characteristics and elemental content of drift particles were determined using a scanning electron microscope with energy dispersive $x$-ray analysis capabilities. Results indicate that elemental content in drift water (mineral residue) may not be equivalent to the content in the recirculating cooling water of the tower. This hypothes is is contrary to basic assumptions in calculating drift emissions. A laboratory study simulating throughfall from 1 to 6 inches of rain suggested that there are more exchange sites associated with litter than live foliage. Leachate from each one inch throughfall simulant removed $3 \%$ of the drift mass from litter compared to 7 to $9 \%$ from 1 ive foliage. Results suggest that differences in retention are related to chemical properties of the drift rather than physical lodging of the particle residue. To determine the potential for movement of driftderived chromium to surface streams, soil-water samplers (wells) were placed along a distance gradient to Little Bayou Creek. Samples from 
two depths following rainstorms revealed the absence of vertical or horizontal movement with maximum concentrations of $0.13 \mathrm{ppb}$ at 50 meters from the tower. Preliminary model estimates of drift deposition are compared to deposition measurements. Isopleths of the predicted deposition are useful to identify areas of maximum drift transport in the environs of the gaseous diffusion plant. 
TABLE OF CONTENTS

Page

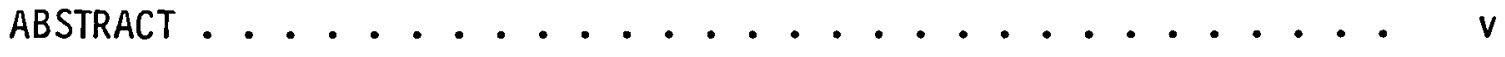

LIST OF FIGURES ...................... ix

LIST OF TABLES ..............................

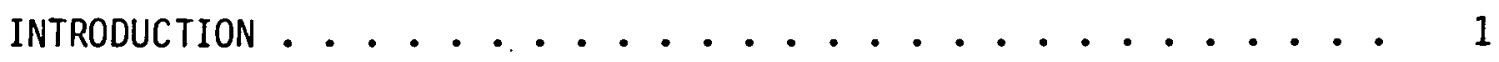

DESCRIPTION OF THE SITE AND ENVIRONS ............ 2

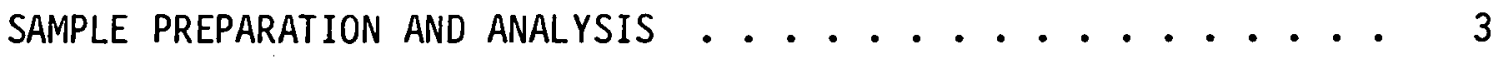

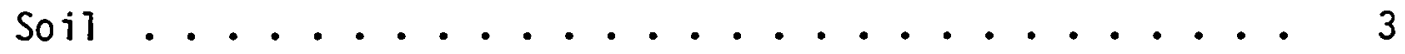

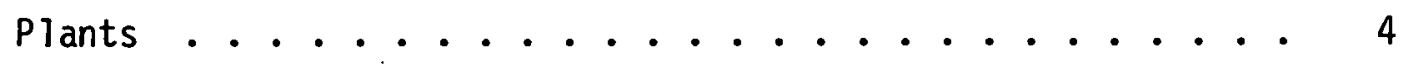

Water (Soil) and Drift Residue ............ 4

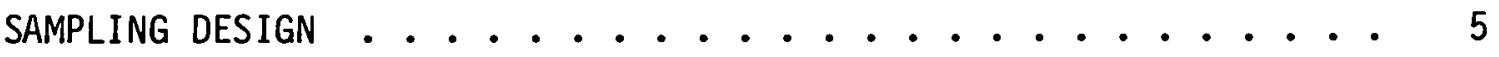

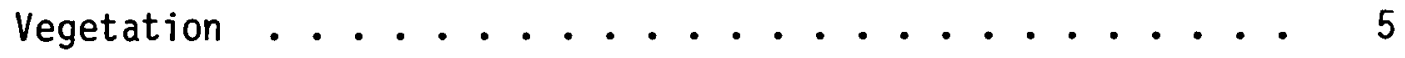

Ground Water .................... 5

RESULTS AND DISCUSSION ...................... 7

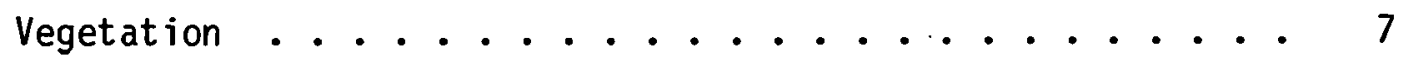

Ground Water .................. 13

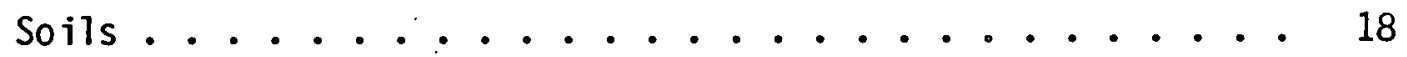

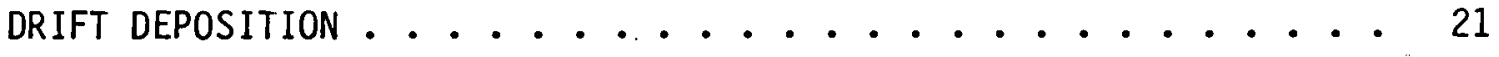

Model Predictions ...................... 21

Measured Drift Deposition . . . . . . . . 25

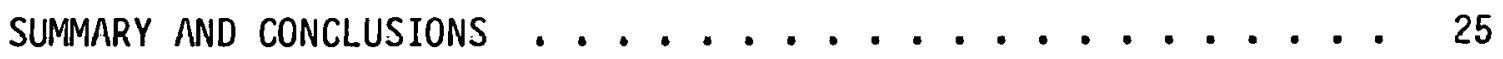

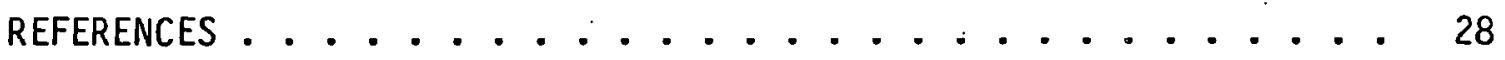




\section{THIS PAGE}

\section{WAS INTENTIONALLY \\ LEFT BLANK}




\section{LIST OF TABLES}

Table

$\underline{\text { Page }}$

1 Chromium concentration ( $p p b \pm 1$ SE) in soil water along a distance gradient at two depths . . . . . . . . 15

2 Duncan's multiple range test ............. 16

3 Chromium concentration of litter and soils, and edaphic characteristics of soils from sample wells........ . 19

4 Wind direction distribution at Paducah (calms are distributed in proportion to frequency) . . . . . . . 22 


\section{THIS PAGE}

WAS INTENTIONALLY

LEFT BLANK 


\section{LIST OF FIGURES}

Figure

Page

1 Location of sampling stations northeast of the C-637 cooling tower. Each transect ( $A$ thru E) is $11.25^{\circ}$ from adjacent transects. Triplicate samples (litter and foliage) were collected at the intersections of each

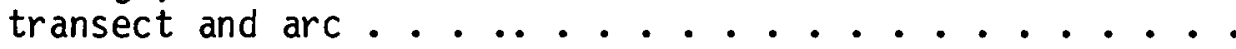

2 Chromium concentration (ppm) in fescue litter (a) and foliage (b) depicting decreasing concentration with increasing distance. Each data point $(a, b)$ represents the mean of triplicate samples. Mean concentration from all transects combined (c) illustrated the 4 to 5 fold difference between litter and foliate $(n=15)$......

3 Retention of drift on fescue foliage and litter, following application of water to simulate throughfall equivalent to from 1 to 6 inches of rain (1.27 liters to $0.05 \mathrm{~m}^{2}$ plot $=$ 1 inch) ....................

4 Electron micrographs of drift deposits: (a) upper surface of fescue foliage; (b) lower surface with deposits aligned along a vein; (c) deposits from recirculating cooling water evaporated to dryness. Particle diameters ranged from 5 to

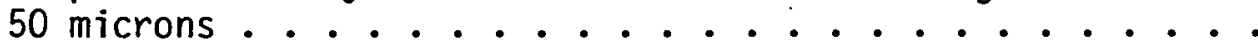

5 Predicted chromium deposition $\left(10^{-4} \mu \mathrm{g} / \mathrm{m}^{2} \mathrm{sec}\right.$, annual average) for all cooling towers (values of 10 to 10,000 near the towers) . . . . . . . . . . . . . .

6 Deposition flux of chromium from the $\mathrm{C}-633$ cooling tower $\left(u g / m^{2} \mathrm{hr}\right)$. Each point depicts the mean $( \pm 1 \mathrm{SE})$ of triplicate samples ................... 


\section{INTRODUCTION}

To meet the demands of enriched uranium required for national defense and commercial nuclear reactors, the Department of Energy (DOE) operates a process facility at Paducah, Kentucky. Enrichment of the uranium is gained in the gaseous diffusion process. The primary plant, the diffusion cascade, contains a physical process in which $U_{6}$ is fed into the system, pumped through the diffusion stages and eventualiy removed as UF 6 enriched in fissionable uranium-235 isotope. Other enrichment plants are located at Oak Ridge, Tennessee and Portsmouth, Ohio. Ancillary processes include a recirculating water cooling system into which the heat of compression is rejected to the atmosphere by cooling towers.

Four recirculating water cooling systems (14 cooling towers) at the Paducah facility dissipate up to $1900 \mathrm{MW}$ of heat depending upon operating level of the plant. To prevent corrosion damage to the cooling condensers a proprietary chromated compound, OROCOL GDP, marketed by Betz Laboratories, Inc., is added daily (200 to 300 pounds) to the make-up water. Chromate concentration of the recirculating water is maintained at approximateiy $20 \mathrm{ppm}$. Drift and windage from the 14 mechanical draft cooling towers represents a potential pathway for introduction of increased levels of trace elements to the terrestrial environment by atmospheric dispersion. This report summarizes a series of field studies conducted at the Paducah site. These studies are complemented by laboratory studies conducted at the Oak Ridge National Laboratory to illustrate the behavior and fate of drift chemicals (chromium) and the potential for environmental impacts from dcposition. 
DESCRIPTION OF THE SITE AND ENVIRONS

The Paducah Gaseous Diffusion Plant (PGDP) is located in McCracken County, Kentucky, about 6 kilometers ( 4 miles) south of the Ohio River and 32 kilometers ( 20 miles) east of the confluence of the Ohio and Mississippi Rivers. The city of Paducah is located 19 kilometers (12 miles) east of the plant. The five major process buildings and related support facilities are within a 350 hectare (750 acres) fenced enclosure. A buffer area extending up to 365 meters in breadth includes an additional 319 hectares (787 acres). Another 863 hectares (2132 acres) has been leased or deeded to the State of Kentucky and is utilized as a wild life management area.

The landscape of the area is neariy level to gently sloping with poorly drained soils. Drainage from the plant area is divided almost equally to Little Bayou Creek, 425 meters east of the plant, and Big Bayou Creek 1200 meters to the west. The soils are characterized by a brittle fragipan $45 \mathrm{~cm}$ below the surface layer. The major soils are classified in the Calloway and Henry series and were developed in more than 1.2 meters ( 4 feet) of loess on uplands and in alluvium washed from loess on stream terraces (Humphrey 1976). The soils are moderately permeable above the fragipan with restricted root and water penetration below the pan. The soil properties of the Calloway and Henry series are considered unfavorable for absorption fields and lagoons. Soils of the series are generally acid ranging in $\mathrm{pH}$ from 4.7 to 6.2.

Much of the region beyond the boundaries of the enrichment facility and wildlife management area is cultivated in garden and field crops 
with soybeans, hay and tobacco as major produce. With in the fenced enclosure and buffer zones the landscape is maintained in fescue grass. Stream banks of little Bayou and Big Bayou Creeks are typical riparian communities, with river birch, sycamore, black willow and cottonwood as dominant species. Upland hardwoods are predominantely oak-hickory forests. Southern red oak, shagbark hickory and post oak are the dominant canopy species. Understory species include persimmon, black cherry and blackgum. The area leased to the State of Kentucky as a wildlife area is managed by annual mowing of alternating strips which results in is land communities dominated by sassafras, cherry and sumacs within the grassland.

\section{SAMPLE PREPARATION AND ANALYSIS}

Soi1

Total chromium analyses for soils were determined by neutron activation techniques. Puiverized samples were irradiated for 2 days at a thermal neutron flux of $5.8 \times 10^{11}$ neutrons $\mathrm{cm}^{-2} \mathrm{sec}^{-1}$. The ratio of the thermal to resonance flux was 3000 . Each sample was counted on a 4096 multichannel analyzer -Ge(Li) gamma-ray spectrometer. The spectra were analyzed with a computer program for $G e(L i)$ spectra resolution and isotope identification. Oxidation states of driftderived chromium in soils were identified using a phosphoric acid, chromium spike, anion exchange procedure for extraction followed by atomic absorption (AA) determinations. 
$\underline{\text { Plants }}$

Plant materials were oven dried $(24 \mathrm{hr})$ at $100^{\circ} \mathrm{C}$ and ground in a Wiley Mill with a 20-mesh screen. A one gram aliquot of oven-dried sample was placed in a preweighed, annealed aluminum dish for ashing. The samples were then placed in a cold muffle furnace where the temperature was slowly elevated to $550^{\circ} \mathrm{C}$ for total combustion at $24 \mathrm{hr}$. The ashed material was removed to a desiccator and allowed to reach room temperature. From 2 to $5 \mathrm{ml}$ of concentrated nitric acid was added to the ash and agitated until the ash was in solution; then $0.1 \mathrm{~N}$ nitric ac id was used to wash the contents into a funnel lined with Whatman No. 42 ashless filter paper and diluted in distilled water to $25 \mathrm{ml}$. The procedure was tested for chromium with certified plant materials (National Bureau of Standards, Certificate of Analysis, Standard Reference Material 1571 - Orchard Leaves.). Elemental concentrations of chromium were determined by atomic absorption spectrophotometry.

\section{Water (Soil) and Drift Residue}

Soil water samples were collected in acid washed polyethylene bottles, filtered to remove particles and analyzed for total chromium using atomic-absorption techniques with graphite furnace attachment for microdeterminations.

Particles (salts) derived from the recirculating cooling water were located on plant surfaces using a scanning electron microscope. Elemental analyses of the mineral residue were determined by measuring the $x$-ray signal induced by a $25 \mathrm{kv}$ electron beam focused on individual particles. The scanning electron microscope was interfaced with an analyzer for spectral resolution. 
SAMPLING DESIGN

\section{Vegetation}

Wind direction is uniformly distributed (annual wind rose) throughout the plant area (Fig. 1) due to the low, flat character of the landscape. However, a slightly predominant SSW wind (20\% frequency) would be expected to disperse the major drift contaminants to the north northeast of the plant. Vegetation sample plots were located along the axis of the predominant wind direction from the $\mathrm{C}-637$ tower in five radial transects (Fig. 1). Each transect.was skewed $11.25^{\circ}$ from adjacent transects such that the angle formed between 3 sequential transects $(A B C, B C D$, or $C D E)$ represented a $22.5^{\circ}$ compass sector typical of computer output data. Harvest plots were located at 30 meter $(100 \mathrm{ft})$ intervals for the first 300 meters and at 300 meter intervals thereafter to 1500 meters (5000 ft). Live foliage of fescue grass (Festuca arundinacea Schreb.) and decaying fescue litter were collected from triplicate $300 \mathrm{~cm}^{2}$ circular plots and analyzed for chromium.

\section{Ground water}

Soil water samplers ( 3 replications at 2 depths) were placed at five sites along a distance gradient from the $C-637$ cooling tower to Little Bayou Creek at 1300 meters. Samples wells were placed at the hardpan ( $\sim 60 \mathrm{~cm}$ deep) and one-half the distance from the pan to the surface $(\sim 30 \mathrm{~cm})$. Samples were collected at 24 and 48 hours following a rain storm, and analyzed for total chromium. 


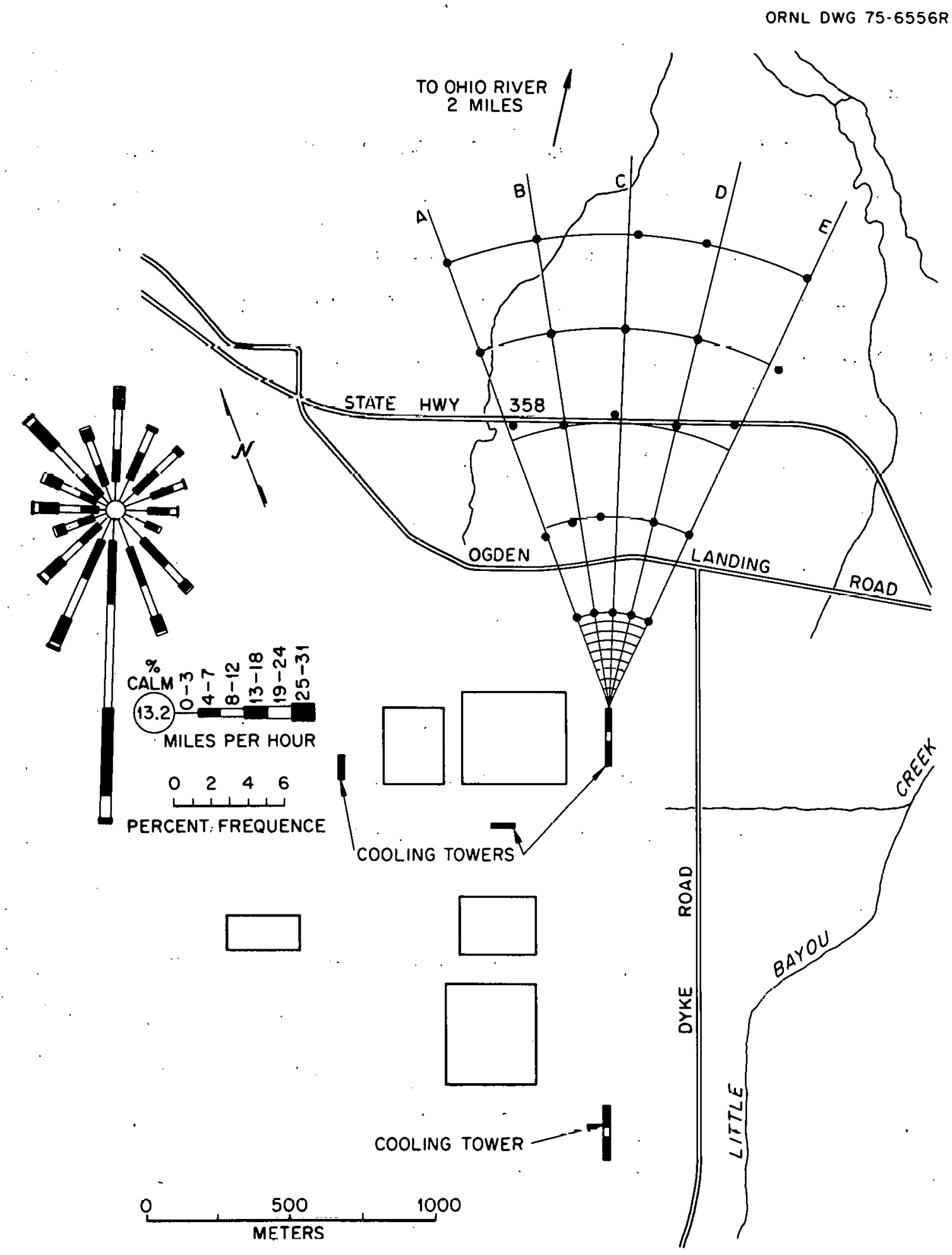

Fig. 1. Location of sampling stations northeast of the C-637 cooling tower. Each transect (A thru E) is $11.25^{\circ}$ from adjacent transects. Triplicate samples (litter and foliage) were collected at the intersections of each transect and arc. 


\section{7 \\ RESULTS AND DISCUSSION}

Vegetation

There was uniformity of drift contamination among the transects (Fig. $2 \mathrm{a}$ and 2b) in the direction of predominant wind dispersion, with a rapid dilution of the contaminant in the environs (Fig. 2c) as shown by the mean concentrations for all transects. Maximum concentrations within 15 meters of the tower basin ranged from $251 \pm 19 \mathrm{ppm}$ in foliage to $1813 \pm 56 \mathrm{ppm}$ in litter. At the perimeter fence ( $\simeq 100$ meters) chromium concentration in foliage $(37.0 \pm 4.4 \mathrm{ppm})$ and litter (141.1 \pm $11.7 \mathrm{ppm}$ ) were still two to three orders of magnitude greater than background levels $(0.52 \pm 0.1 \mathrm{ppm}$ and $2.9 \pm 0.4 \mathrm{ppm}$ for foliage and litter respectfuliy). Drift concentrations (chromium) remained significantly greater than controls at the perimeter of the buffer zone $(300 \mathrm{~m})$ between the fence and wildlife management area, reaching background levels at 1.5 kilometers.

The results of the vegetation survey are similar to the findings in a study conducted at the Oak Ridge Gaseous Diffusion Plant (Taylor et al. 1975). Concentrations in foliage at Paducah are consistently lower at all distances by a factor of 3 to 4 than the levels determined at Oak Ridge.

The 2- to 4-fold difference in chromium concentration noted between foliage and litter of this study and in the previous study (Taylor et a1. 1975) suggests that there are more exchange sites associated with the litter than with the foliage. It is hypothesized that the differences in concentration between the foliage and litter 


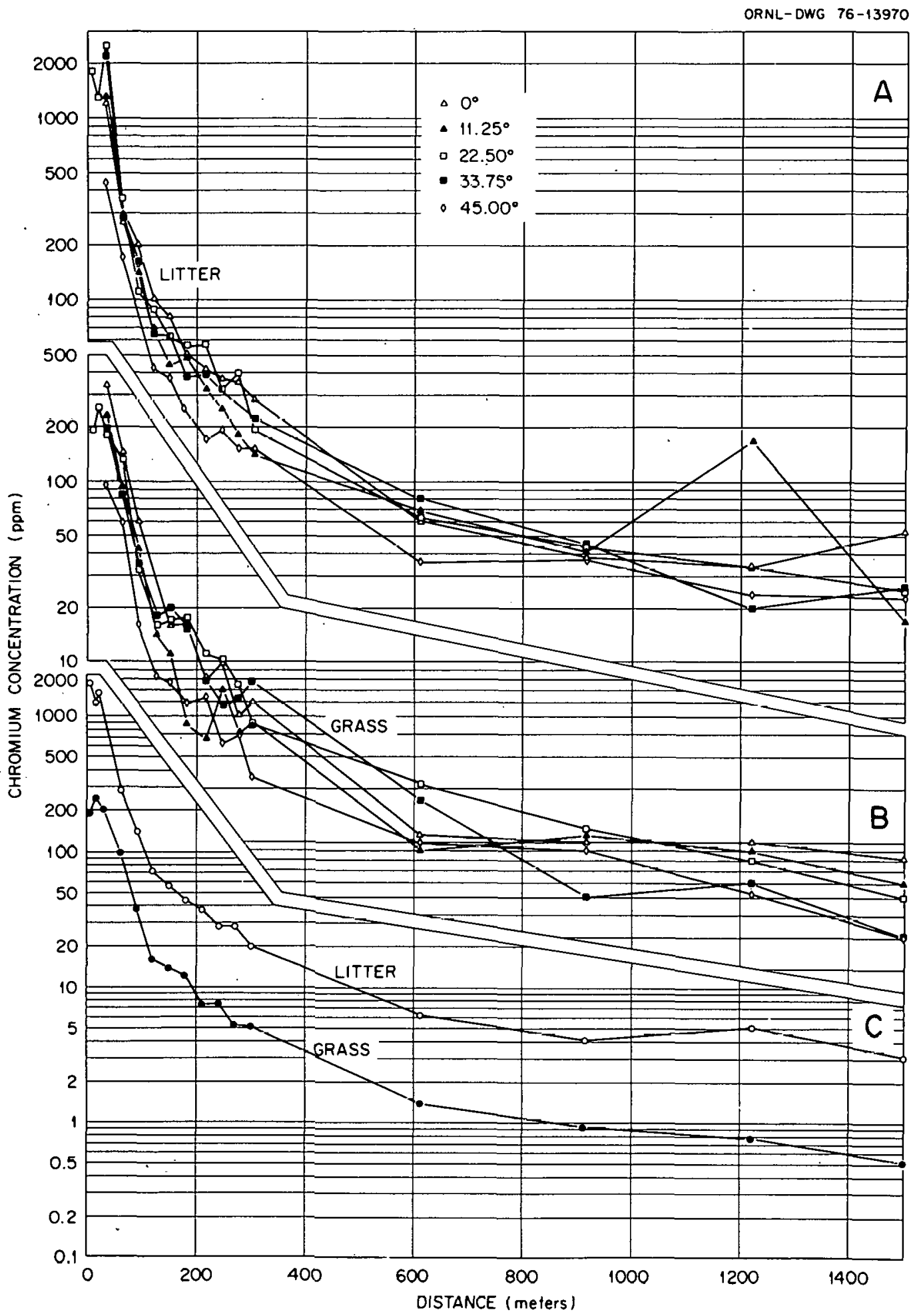

Fig. 2. Chromium concentration (ppm) in fescue litter (a) and fo1.iage (b) depicting decreasing concentration with increasing distance. Each data point $(a, b)$ represents the mean of triplicate samples. Mean concentration from all transects combined (c) illustrated the 4 to 5 fold difference between litter and foliate $(n=15)$. 
are related to the chemical properties of chromium rather than the physical trapping of the chemical residue. Drift deposited as hexavalent chromium on foliage should remain relatively water soluble, whereas the deposition on litter would likely be reduced to the less soluble trivalent species by humic substances and subsequent ly become bound to the decaying mat.

In a laboratory study (Taylor et al. 1978) foliage and litter were leached to simulate throughfall from 1 to 6 inches of rain. The content of $\mathrm{dr}$ ift in the leachate indicated that the loss rate of chromium from grass foliage was 2 to 3 times greater than losses from litter (Fig. 3 ). Approximately 7 to $9 \%$ of the initial drift contaminant was removed from foliage with each throughfall simulant in comparison to on ly $3 \%$ from the Titter. These data support the hypothesis that the difference in concentration between foliage and litter is likely related to a differential solubility of chromium in two oxidation states $\left(\mathrm{Cr}^{+3}\right.$ and $\left.\mathrm{Cr}^{+6}\right)$ and subsequent field losses due to weathering.

Following the leaching experiment.fescue foliage was examined using a scanning electron microscope to determine the sites of drift contamination and size characteristics of drift particles. Both upper and lower surfaces of leaves were examined from samples collected at 60 and 300 meters. Drift particles observed were either deposited as particulates or droplets which subsequently dried leaving the mineral residue. Particle density on the upper surfaces (Fig. 4a) of leaves collected at 60 meters was much less than on the lower surfaces (Fig. 4b), and at 300 meters particle density on both surfaces was less than the corresponding surfaces at 60 meters. Recirculating cooling 


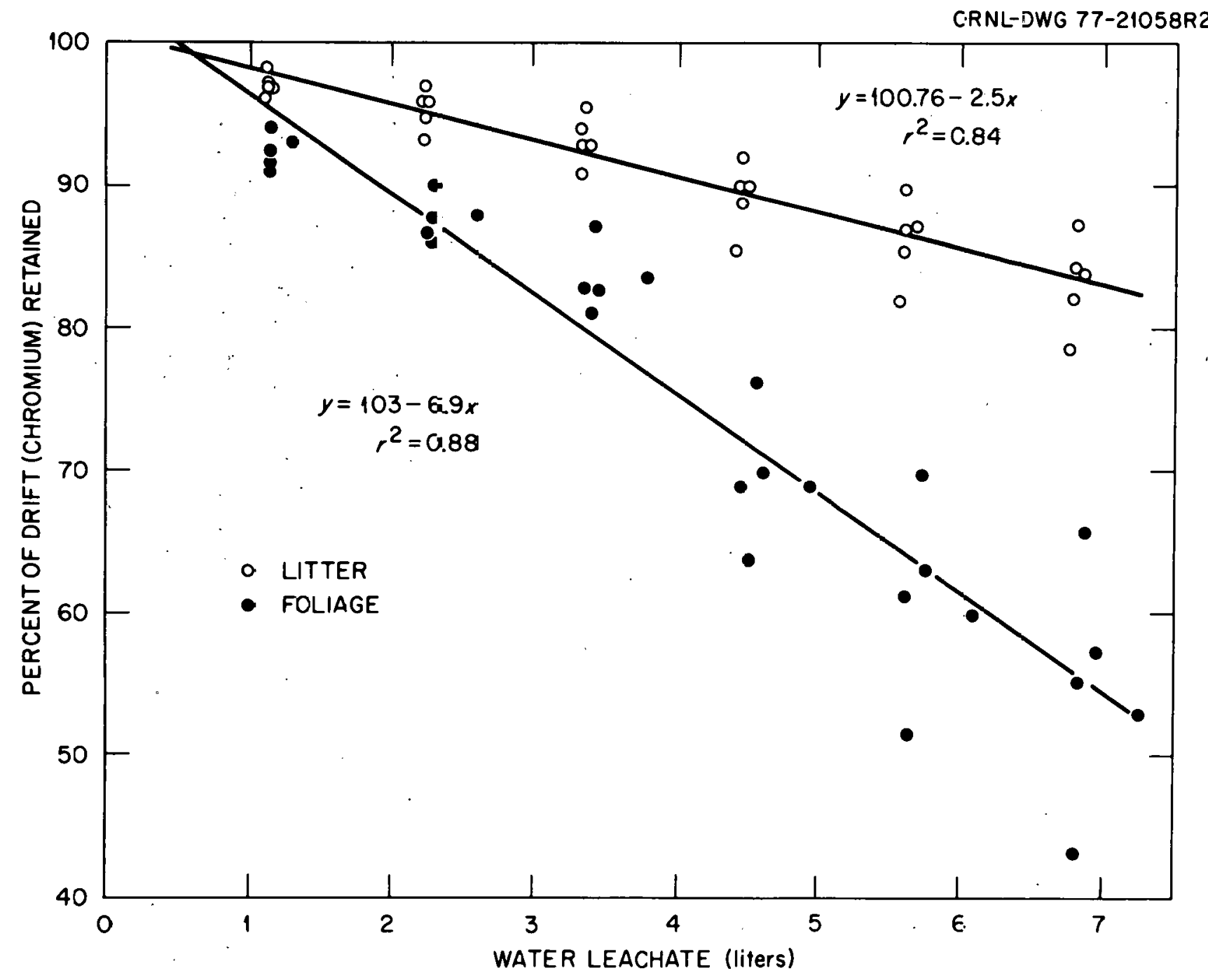

Fig. 3. Retention of drift on fescue foliage and litter, following application of water to simulate throughfall equivalent to from 1 to 6 inches of rain ( 1.27 i iters to $0.05 \mathrm{~m}^{2} \mathrm{plot}=1$ inch). 

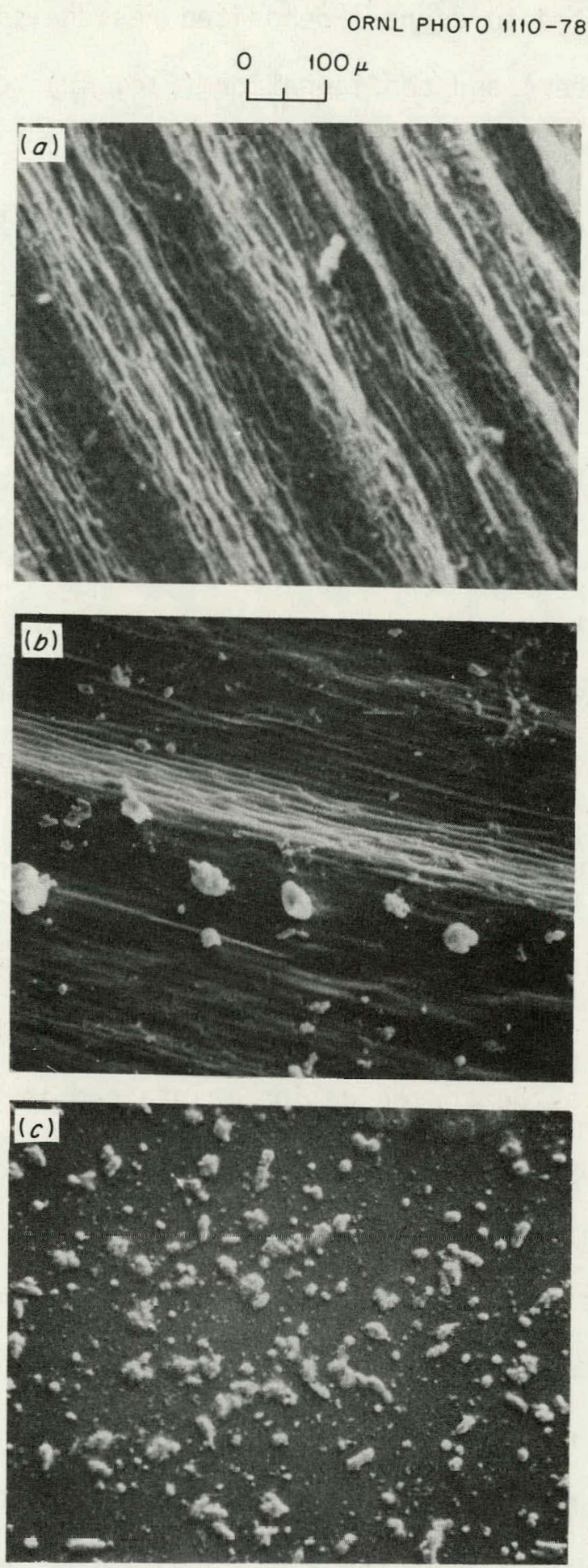

Fig. 4. Electron micrographs of drift deposits: (a) upper surface of fescue foliage; (b) lower surface with deposits aligned along a vein; (c) deposits from recirculating cooling water evaporated to dryness. Particle diameters ranged from 5 to 50 microns. 
water (RCW) evaporated to dryness deposited residue similar in size (6 to 40 microns diameter) and configuration (Fig. 4c) to the deposits (5 to 50 microns diameter) observed on the foliage.

To test whether the foliar deposits were actually drift derived, energy dispersive $x$-ray analyses were made on the drop residue (Fig. 4c) and compared by similar analyses to spectral characteristics of foliar deposits (Fig. 4b). The electron induced $x$-ray fluorescence analyses showed that particles on the foliage contained elements common to the chemistry of the cooling water drop $(\mathrm{Na}, \mathrm{Mg}, \mathrm{Si}, \mathrm{S}, \mathrm{Cl}, \mathrm{K}, \mathrm{Ca}$ and $\mathrm{Fe})$. Each of these elements are contained in the RCW following concentration by several cooling cycles or in the make-up water. Analyses of washed and unwashed leaves from control areas did not produce emissions spectra.

All particles examined did not contain the full spectrum of elements as found in the cooling water drop. This suggests that the concentration of a specific element in individual drift droplets may not be equivalent to the concentration maintained in the recirculating water. This finding is important to the state-of-the-knowledge in calculating the drift emissions since a common assumption in cooling tower drift studies is that drift droplets contain the same mineral concentration as the circulating water. The low density of deposits on the upper surfaces of the leaves suqqests a field loss due to weathering. The chromium maintained in the cooling water for corrosion inhibition could not be detected by the $x$-ray analyses as the concentration (9 ppm) is below the limit of detection ( 0.1 to $1 \%$ ) by the energy dispersive technique. 
Ground Water.

Paducah Gaseous Diffusion Plant liquid effluents flow to the Ohio River via the Little Bayou and Big Bayou Creeks. Little Bayou Creek is surrounded by government property (Department of Energy and Tennessee Valley Authority) along its entire length whereas Big Bayou Creek passes through privately owned farm 1and. The National Pollutant-Discharge Elimination System (NPDES) permit specifies allowable concentrations for pollutants in plant discharges. In order to meet the discharge limit of $0.05 \mathrm{ppm}$ hexavalent chromium, blowdown from the four recirculating cooling systems ( 700,000 gpd) is delivered to the Plant Liquid Effluent Pollution Control Facility $(C-616)$. This facility was designed to decrease the concentration of total chromium in Big Bayou and Little Bayou Creeks by reducing the hexavalent chromium to the trivalent state and subsequently precipitating it in a clarifer using lime. The clarified water then passes to a $26 \times 10^{6}$ galion lagoon for equalization and further settling before it is discharged to Big Bayou Creek. When the gaseous diffusion plant is fully uprated (1981), with a blowdown rate of $1.8 \times 10^{6}$ gallons per day, the lagoon will provide a 14 day retention time.

The performance of the facility prior to the addition of new cooling towers in the fall of 1977 indicated that the program was operating at design specifications with chromium concentrations in Little and Big Bayou Creeks within the NPDES limit of $0.05 \mathrm{ppm}$ (Conrad 1978). However, even with all blowdown diverted to the Plant Liquid Effluent Pollution Control Facility there still remained a potential for chromium concentrations in nearby Little Bayou Creek to exceed 
NPDES limits either by direct deposition of drift water or from transport of drift derived chromium by soil moisture flow. For example, the soils of the area are of the Calloway and Henry series, developed from loess deposits and characterized by an (impermeable) fragipan from 10 to $70 \mathrm{~cm}$ below the surface. This edaphic feature could provide a significant pathway for the contamination of Little Bayou Creek by channelization of drift contaminated soil water along the fragipan.

In order to test this hypothesis, soil water samples were collected from each of five sites aiong a distance gradient from the cooling tower to Little Bayou Creek at 1300 meters. Samples were collected at the hardpan ( $~ 60 \mathrm{~cm}$ deep) and one-half the distance from the pan to the surface $(\sim 30 \mathrm{~cm})$ at 24 and 48 hours following a rain storm.

The analytical results suggest that the chromium concentration in soil water (shallow wells) at 60 and 200 meters from the tower is greater than the concentration at the hardpan (Table 1). However, linear regression analysis between concentration and depth indicated that there was no correlation. Subsequently, sample data were combined, disregarding depth, and analyzed by distance using a one way analysis of variance. The results indicated that there was a significant difference (5\% level) between mean concentration at 60 meters and the other distances, but failed to distinguish differences between those distances. The data were further analyzed according to Duncan's multiple range test by logarithmic transformation to stabilize the variance. ' The results (Table 2) identify the differences in chromium concentration in soil water between 60 and 1260 meters from the cooling tower. The 
Table 1. Chromium concentration ( $p p b \pm 1 \mathrm{SE}$ ) in soil water along a distance gradient at two depths

\begin{tabular}{lcccccc}
\hline & \multicolumn{5}{c}{ Distance (meters) } \\
\cline { 2 - 6 } & 60 & 200 & 410 & 950 & 1260 \\
\hline Shallow we 11* & $0.130 \pm 0.027$ & $0.048 \pm 0.015$ & $0.029 \pm 0.004$ & $0.051 \pm 0.008$ & $0.036 \pm 0.007$ \\
Deep we 11** & $0.085 \pm 0.028$ & $0.029 \pm 0.006$ & $0.030 \pm 0.006$ & $0.050 \pm 0.009$ & $0.064 \pm 0.009$ \\
Combined & $0.112 \pm 0.019$ & $0.038 \pm 0.008$ & $0.029 \pm 0.003$ & $0.051 \pm 0.006$ & $0.050 \pm 0.007$ \\
\hline
\end{tabular}

$\star 30$ to $40 \mathrm{~cm}$.

$\star \star 50$ to $75 \mathrm{~cm}$. 
Table 2. Duncan's multiple range test

\begin{tabular}{|c|c|c|c|c|}
\hline $\begin{array}{l}\text { Distance } \\
\text { (meters) }\end{array}$ & $n$ & $\begin{array}{c}\text { Mean by } \\
\log \\
\text { concentration }\end{array}$ & \multicolumn{2}{|c|}{ Groupings* } \\
\hline 60 & 15 & -2.415900 & A & \\
\hline 950 & 18 & -3.089200 & B & \\
\hline 1260 & 18 & -3.185600 & B & c \\
\hline 200 & 16 & -3.493200 & B & $c$ \\
\hline 410 & 14 & -3.602700 & & c \\
\hline
\end{tabular}

*Means with same letter are not significantly different $(P<0.05)$.

concentration at 60 meters $(0.112 \mathrm{ppb})$ is significantly different $(P<0.05)$ from the concentrations at all other distances, while the concentrations at 200,950, and 1260 meters are different from the 410 meter distance. The concentration at 410 meters $(0.029 \mathrm{ppb})$ was the lowest along the gradient but not statistically different from the concentration at the most distant plot (1260 meters).

At 60 meters from the cooling tower there is a higher chromium concentration $(0.112 \mathrm{ppb})$ in soil water than at 1260 meters $(0.05 \mathrm{ppb})$ near Little Bayou Creek. Even though the concentration at 60 meters is statistically significant it is several orders of magnitude lower than the NPDES limit of $0.05 \mathrm{ppm}$. It should be noted that the concentrations are within or below the range reported for spring water on the Walker Branch Watershed at Oak Ridge (Auerbach et al. 1976). It is concluded from this study that the transport of drift derived chromium in soil 
water is not a significant pathway for introducing the regulated substance into the stream.

However, during 1977 and 1978 (following the construction of new cooling towers and the C-616 facility) there were numerous NPDES violations of $\mathrm{Cr}^{+6}$ in Big Bayou and Little Bayou Creeks (Conrad 1978a). These violations were due to "blowout or windage" losses caused by high winds ( $>20 \mathrm{mph}$ ) perpendicular to the cooling towers, and the subsequent surface transport of the cooling water to streams: Tests have shown that almost all of the losses are from the new towers. The area receiving the majority of windage has been limited to the first 5 meters from the basin. Maximum depths $(\mathrm{cm} / \mathrm{hr})$ of 10 to $0.1 \mathrm{~cm}$ of windage water have been determined at 0.5 to 5 meters distance. The winds responsible for the losses are associated with storm fronts. Transport of chromatecontaining windage is by runoff, such that noncompliance with NPDES permit limits is usually detected in Little Bayou Creek with in 2 days following windage loss.

In order to reduce the NPDES violations of $\mathrm{Cr}^{+6}$ in Big Bayou and Little Bayou Creeks, wind screens have been installed in the center line of the new and in some old towers. Since most of the windage loss is deposited within 5 meters of the towers, the area has been curbed, covered with a polyethylene cover and contoured to drain into the existing RCW basins. These actions should eliminate the recurring NPDES $\mathrm{Cr}^{+6}$ violations in the Bayou Creeks except for periods of severe storms. Future studies are needed to determine the success of the - alterations in reducing windage and to determine the contribution of $\mathrm{Cr}^{+6}$ to the streams from drift deposition and surface runoff following major storms. 
Soils

Composite soil samples were taken from each well at the two depths and analyzed for texture, $\mathrm{pH}$, and organic matter content (Table 3 ). Chromium concentration in litter was indicative of drift deposition along the distance gradient to the Little Bayou Creek, ranging from $123.8 \pm 7.8 \mathrm{ppm}$ at 60 meters to $1.2 \pm 0.1 \mathrm{ppm}$ at 1260 meters. Surprisingly, total soil chromium indicated that there was very little accumulation even at close-in distances (Table 3). Among the soil properties determined (Table 3), only organic matter content offers any plausible explanation for the lack of accumulation. In the presence of organic matter, hexavalent chromium is easily reduced and subsequently bound to organic particles as trivalent chromium. The kinetically inert trivalent chromium is the most.stable oxidation state of chromium and therefore would accumulate with chronic deposition. The low organic matter content $(0.5$ to $1.0 \%$ ) of the Paducah soils (Calloway and Henry series) has a low potential for the chemical reduction of the chromated drift to the less soluble trivalent species. Drift derived chromium in the soils is likely continuously removed through weathering (rain and runoff). At 60 meters total soil chromium $(69.3 \pm 2: 3 \mathrm{ppm})$ was $15 \%$ greater than controls $(60.6 \pm 1.9 \mathrm{ppm})$ at 1260 meters. At Oak Ridge, Tennessee soils contaminated by drift showed chromium accumulations to 180 meters downwind ranging up to a 10 fold increase at 15 meters (Tayior et al. 1974).

In order to determine the chemical forms (oxidation states) of the dr ift contaminant, a laboratory study was conducted to identify the oxidation state of the chromium in soils from the 0ak Ridge site. Oak 
Table 3. Chromium concentration of litter and soils, and edaphic characteristics of soils (Calloway and Henry-series) from sample wells

\begin{tabular}{|c|c|c|c|c|c|}
\hline & \multicolumn{5}{|c|}{ Meters } \\
\hline & 60 & 200 & 410 & 950 & 1260 \\
\hline $\begin{array}{l}\text { Chromium in } \\
\text { litter }(\mu g, g)\end{array}$ & $123.87 \pm 7.79$ & $20.33 \pm 0.40$ & $4.22 \pm 0.65$ & $1.24 \pm 0.15$ & $1.15 \pm 0.13$ \\
\hline $\begin{array}{l}\text { Chromium in } \\
\text { soil }(\mu \mathrm{g} / \mathrm{g})\end{array}$ & $69.27 \pm 2.26$ & $63.57 \pm 1.10$ & $61.26 \pm 1.49$ & $61.03 \pm 1.68$ & $60.60 \pm 1.94$ \\
\hline $\begin{array}{l}\text { So il organic } \\
\text { matter }(\%)\end{array}$ & $1.07 \pm 0.33$ & $0.85 \pm 0.30$. & $0.49 \pm 0.14$ & $0.53 \pm 0.11$ & $0.78 \pm 0.16$ \\
\hline $\mathrm{pH}$ & $5.8 \pm 0.2$ & $5.2 \pm 0.2$ & $4.9 \pm 0.1$ & $5.1 \pm 0.1$ & $5.2 \pm 0.1$ \\
\hline Sand $(\%)$ & $9.08 \pm 0.36$ & $9.69 \pm 0.59$ & $9.92 \pm 0.37$ & $9.61 \pm 0.38$ & $10.98 \pm 0.84$ \\
\hline Silt (\%) & $71.65 \pm 2.37$ & $73.61 \pm 0.91$ & $76.11 \pm 0.63$ & $76.48 \pm 0.82$ & $77.54 \pm 0.72$ \\
\hline Clay $(\%)$ & $\therefore \quad 19.94 \pm 2.04$ & $16.23 \pm 0.78$ & $13.87 \pm 0.81$ & $12.49 \pm 0.68$ & $12.48 \pm 2.13$ \\
\hline
\end{tabular}


Ridge soils were used because they contained considerably more chromium (458 ppm) than soils from Paducah (69 ppm) and were indicative of some accumulation. Phosphoric acid standards consisting of known quantities of $\mathrm{Cr}^{+3}, \mathrm{Cr}^{+6}$, and a combination of $\mathrm{Cr}^{+3}$ and $\mathrm{Cr}^{+6}$ were heated and passed through an anion exchange column. The $\mathrm{Cr}^{+3}$ was recovered, whereas. the $\mathrm{Cr}^{+6}$ was retained on the column, indicating that the phosphoric acid did not change the valence of the chromium. Since total chromium in soils can be successfully extracted by phosphoric acid, the above heated acid, chromium spike, anion exchange column procedure offered a potential for identifying the valence state of chromium in soils contaminated by chromated drift. Soils of known total chromium content (drift contaminated) were placed in flasks, spiked with $\mathrm{Cr}^{+3}, \mathrm{Cr}^{+6}$, or a combination of $\mathrm{Cr}^{+3}$ and $\mathrm{Cr}^{+6}$, and allowed to stand overnight. The soils were then treated with phosphoric acid, transferred through the anion exchange column, and the leachate analyzed by $A A$ for chromium. In all samples the quantity of chromium recovered (less the quantity of $\mathrm{Cr}$ added) was in agreement with the initial known total chromium content of the sample. This suggested that the $\mathrm{drift}$ deposited chromium had been reduced to $\mathrm{Cr}^{+3}$ by humic substances in the soils and that the accumulation of chromium observed near the ORGDP cooling towers was the less biologically active $\mathrm{Cr}^{+3}$ species. It is further assumed that the drift derived chromium in the Paducah site soils would behave simarily dependent on the organic matter content. Any $\mathrm{Cr}^{+6}$ in the soils not reduced would remain water soluble and leach readily following rain events. 


\section{DRIFT DEPOSITION}

\section{Model Predictions}

The vegetation study (Fig. 2) has provided evidence of the transport of drift from one cooling tower to the terrestrial environment. Since there are four recirculating water cooling systems (14 cooling towers) at the Paducah facility it is important to know if the deposition from the various towers is additive. It is also important to identify the regions of maximum drift contamination in assessing the potential for effects on biota. In order to estimate these parameters, the annual average deposition was determined using a drift deposition mode 1 .

Drift deposition models require the following input:

At the tower mouth: (1) drift drop size distribution

(2) drift mass emissions

(3) plume temperature and vertical velocity

(4) radius and height of tower mouth.

In the ambient air: (5) wind speed and direction

(6) temperature and relative humidity.

At the Paducah Gaseous Diffusion Plant, only items (4) and (5) were available. The other initial plume characteristics were assumed to be the same as at the Oak Ridge Gaseous Diffusion Plant cooling towers (Hanna and Perry 1973), which are of nearly the same age and design. The total drift flux of chromium at Paducah was obtained considering the recirculating water flow rates of the four cooling systems at the time of the vegetation study (Wrinkie 1974) by multiplying the hypothesized drift water flux by the observed concentration of chromium in the water. 
Observed average annual wind speed is $6 \mathrm{~m} / \mathrm{s}$ and the observed wind direction distribution is given in Table 4. Since ambient temperature and relative humidity information was not available, stabilities and humidities at Paducah were assumed to be the same as at Oak Ridge.

Table 4. Wind direction distribution at Paducah (calms are distributed in proportion to frequency)

\begin{tabular}{lcccccccc}
\hline Direction & N & NNE & NE & ENE & E & ESE & SE & SSE \\
Frequency & 0.050 & 0.070 & 0.053 & 0.053 & 0.043 & 0.037 & 0.030 & 0.062 \\
\hline Direction & S & SSW & SW & WSW & W & WNW & NW & NNW \\
Frequency & 0.076 & 0.175 & 0.087 & 0.059 & 0.039 & 0.048 & 0.046 & 0.072 \\
\hline
\end{tabular}

Considering the limited input information and the many assumptions that must be made, it did not seem practical to apply a long, detailed drift deposition mode 1 to this situation. Consequently, the drift deposition predictions that had been already made at Oak Ridge were modified by simple corrections to yield the predictions of average annual deposition at Paducah (Fig. 5). The model that was used at Oak Ridge is described by Hanna and Perry (1973). It is basically a ballistic trajectory model, following a drift drop as it sinks within the plume, breaks away from the plume into the ambient air, changes size as evaporation proceeds, and finally strikes the ground. The results of this model are generally within a factor of three of the results of the 10 or 12 other acceptable drift models (Chen and Hanna 1978). 


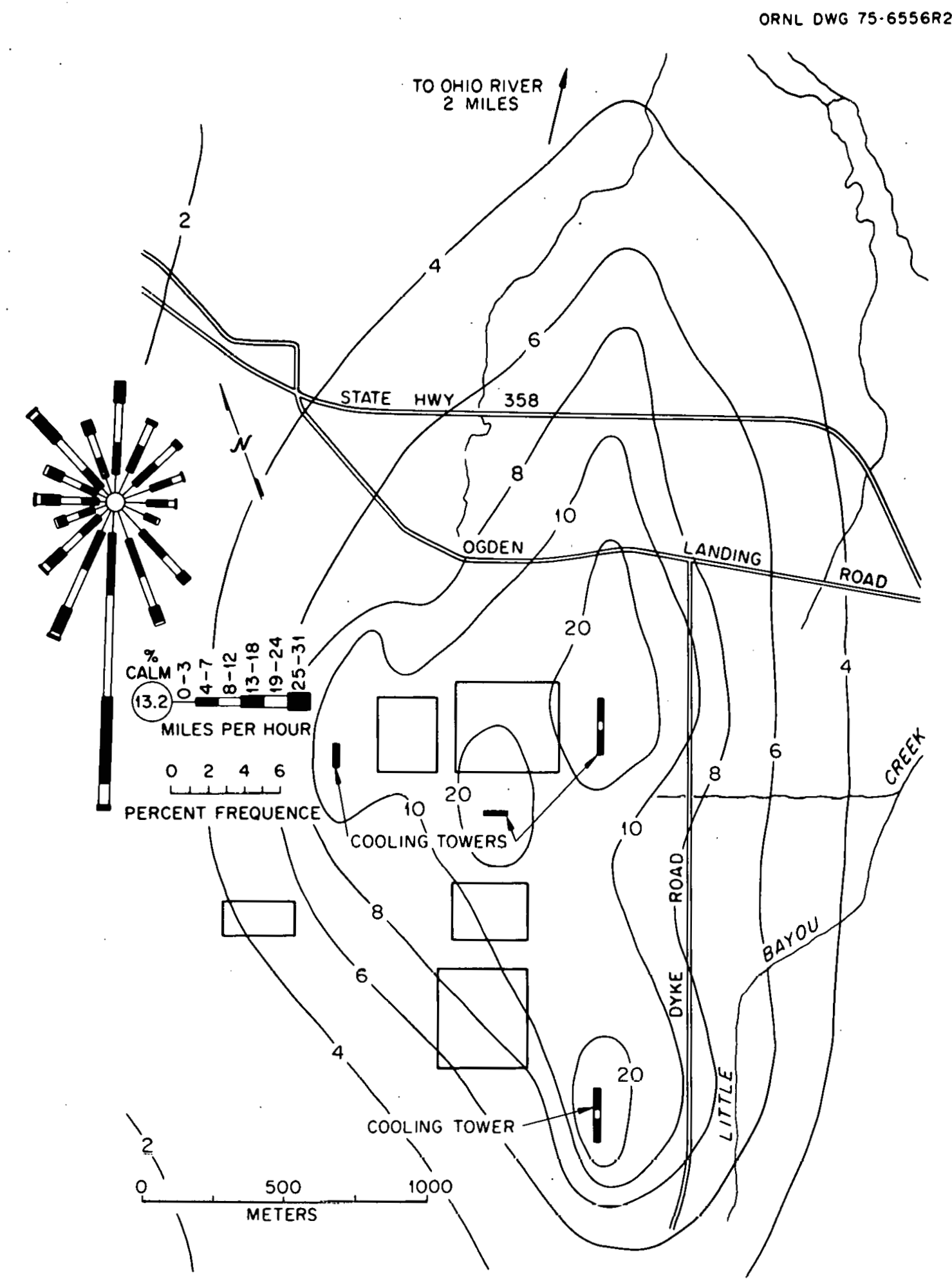

Fig. 5. Predicted chromium deposition $\left(10^{-4} \mu \mathrm{g} / \mathrm{m}^{2} \mathrm{sec}\right.$, annual. average) for all cooling towers (values of 10 to 10,000 near the towers). 
The only meteorological difference between Oak Ridge and Paducah was assumed to be the wind speed and wind direction frequency distributions. The predictions of drift deposition versus distance for constant wind direction in Fig. 8 of Hanna and Perry. (1973) was adjusted slightly to account for the fact that the average wind speed is $33 \%$ higher in Paducah than 0ak Ridge. For given plume rise, a drop will therefore strike the ground at Paducah a distance from the tower $33 \%$ greater at Paducah than at Oak Ridge. However, since plume rise varies as $(U)^{-1 / 3}$, average plume rise at Paducah is $92 \%$ of that at 0ak Ridge. Consequent ly, on the average a drop strikes the ground at Paducah a distance from the tower $0.92 \times 1.33=1.22$ times the distance at 0ak Ridge. Using the chromium emissions for each set of towers at Paducah and the wind direction distribution in Table 1, a map of average annual drift deposition was constructed for the area within about $5 \mathrm{~km}$ of each set of towers. The four maps were superposed to obtain Figure 5, which contains the annual average predicted chromium deposition for all cooling towers at Paducah. Within 300 meters of each cooling tower, the drift deposition is a imost wholly $(>90 \%)$ due to that tower. At distances greater than 500 meters from any tower, the drift deposition is of ten made up of significant contributions from two or more towers.

As information on input items (1) through (6) becomes available, the complete model should be run again using the observed data frnm Paducah. In view of the climatic and source type similarities between Oak Ridge and Paducah, the predictions made in this section should provide fairly reliable estimates in the meantime. 
Measured Drift Deposition

Deposition mass was determined along a distance gradient to 400 meters WSW of the C-633 cooling tower. At the beginning of the sampling period the wind was from the east at 6 to $10 \mathrm{mph}$. During the sample period (6 hrs) the wind shifted such that the plume was over the samplers on ly $18 \%$ of the time. Deposition mass decreased rapidly with increasing distance (Fig. 6) from the tower. The measured deposition was compared to the predicted deposition where the isopleths coincided with sample stations. If the model estimates (Fig. 5) are reduced by a factor of six, thus accounting for the fraction of the time the plume was actualiy over the samplers, predicted deposition is a factor of 2 to 10 greater than the measured values. Considering the uncertainty in the source terms used in the model and the minimal meteorology available the model estimates appear reasonable. Measured deposition at Paducah is a factor of 2 to 3 lower than measurements at 0 ak Ridge (Lee et al. 1973).

\section{SUMMARY AND CONCLUSION}

The vegetation survey has provided evidence of the long term transport and deposition of chromium to terrestrial ecosystem components. Data illustrating a decreased concentration with distance from the cooling towers suggest that most of the deposition is confined to the property of the Department of Energy. Background or near background levels for foliage and litter are attained at $1.5 \mathrm{kjlometers.} \mathrm{Leaching}$ of foliage and litter by water to simulate throughfall indicates that drift derived chromium is subject to removal by rain. Chromium concentrations in litter are indicative of long term accumulation and suggest 


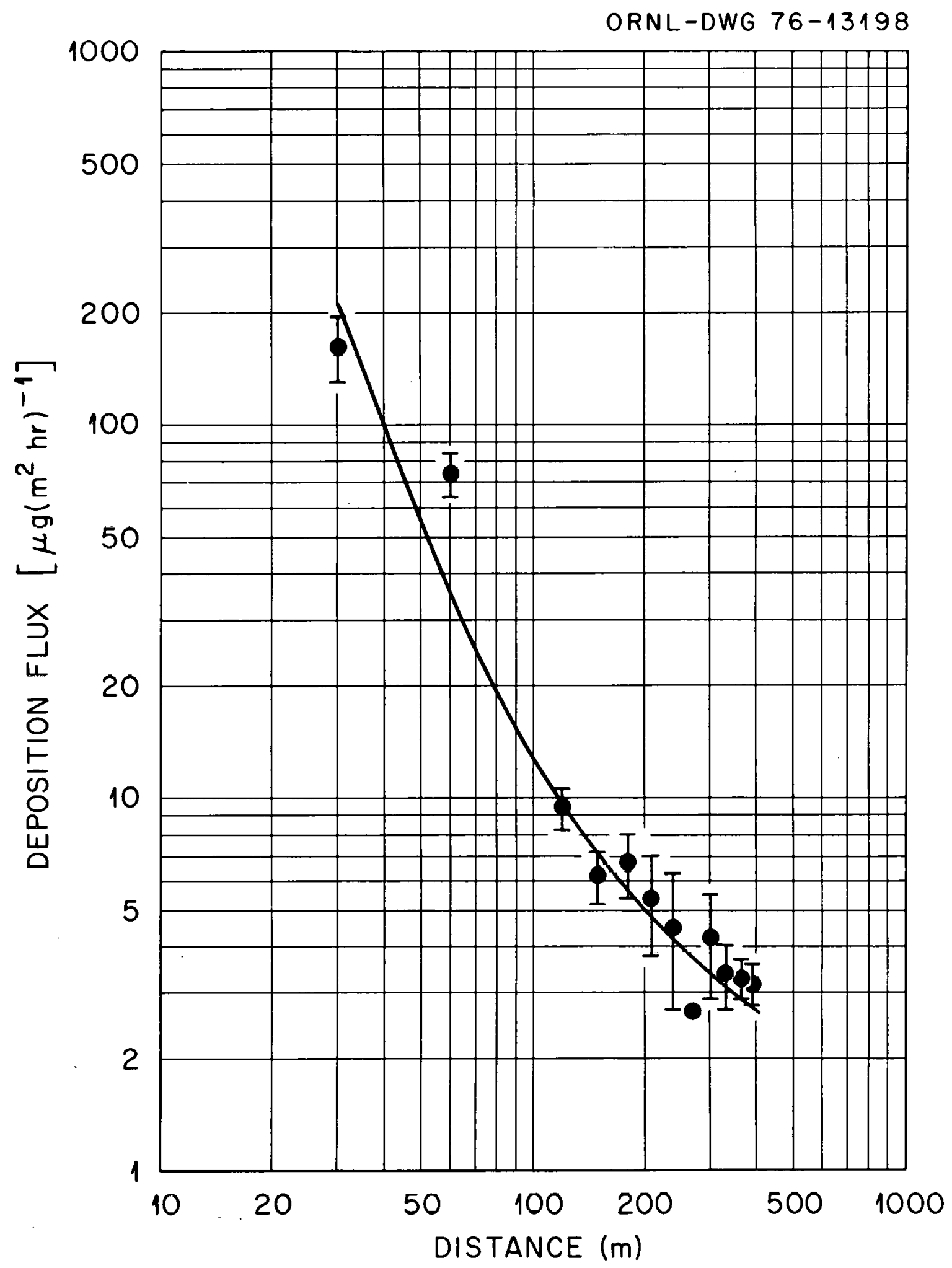

Fig. 6. Deposition flux of chromium from the $\mathrm{C}-633$ cooling tower $\left(\mu \mathrm{g} / \mathrm{m}^{2} \mathrm{hr}\right)$. Each point depicts the mean $( \pm 1 \mathrm{SE})$ of triplicate samples. 
an integrated average between chronic deposition and losses due to weathering. Chromium deposited by drift to soils or lost to soils from vegetation does not accumulate significantiy beyond 200 meters from the towers. Laboratory studies suggest that soil chromium is in the less soluble and less biologically active oxidation state $\left(\mathrm{Cr}^{+3}\right)$. Soil water samples support these data and indicate that the transport of drift derived chromium by soil moisture flow is not a significant pathway for introducing the element into surface streams. Model estimates of deposition (average annual) indicate that approximately 1500 hectares receive cooling tower drift. 


\section{REFERENCES}

Auerbach, S. I., et al. 1977. Environmental Sciences Division Annual Progress Report for period ending September 30, 1976.

ORNL-5257-0ak Ridge National Laboratory, Oak Ridge, Tennessee.

Chen, N. C. J.; and S. R. Hanna. Drift-modeling and monitoring comparisons. Atmos. Environ. (in press).

Conrad, C. (personal communication) November 12, 1977, Union Carbide, Paducah Gaseous Diffusion Plant, Paducah, Kentucky.

Conrad, C. (personal communication) August 29, 178a, Union Carbide, Paducah Gaseous Diffusion Plant, Paducah, Kentucky.

Hanna, S. R., and S. G. Perry. 1973. Meterological effects of the cooling towers at the Oak Ridge Gaseous Diffusion Plant - Part II. Predictions of fog occurrence and drift deposition. ATDL No. 88, P. 0. Box E, Oak Ridge, Tennessee 37830. 39 pp.

Humphrey, M. E. 1976. So jl survey of Ballard and McCracken Counties, Kentucky. U.S. Department of Agriculture, So il Conservation Science, in cooperation with Kentucky Agriculture Experiment Station.

Lee, R. N., Sloot, J.W., and M. A. Wolf. 1973. Measurements of chromate resulting from cooling tower drift at the 0ak Ridge Gaseous Diffusion Plant. Final report to Union Carbide Nuclear, Subcontract No. 11K-24804. Battelle Pacific Northwest Laboratories, Richland, Washington 99352. 
Taylor, F. G., Mann, L., DahIman, R. C., and F. L. Miller. 1975.

Environmental effects of chromium and zinc in cooling-water drift: Cooling Tower Environment-1974. (eds. S. Hanna and J. Pe11) pp. 408-426. ERDA Symposium Series CONF-740302.

Taylor, F. G., Parr, P. D., and F. L. Ball. 1978. Interception and retention of simulated cooling tower drift by vegetation. Cooling Tower Environment-1978. (eds. R. Nietubicz and R. L. Green). pp. I-39-48. Water Resources Research Center Special Report No. 9, University of Maryland, College Park, Maryland.

Wrink le, R. B. 1974. Information relative to chromate distribution tests on the $\mathrm{C}-633$ and $\mathrm{C}-637$ cooling towers. (personal communication) Union Carbide, Paducah Gaseous Diffusion Plant, Paducah, Kentucky. 


\section{THIS PAGE}

\section{WAS INTENTIONALLY}

LEFT BLANK 
ORNL/TM-6131

INTERNAL DISTRIBUTION

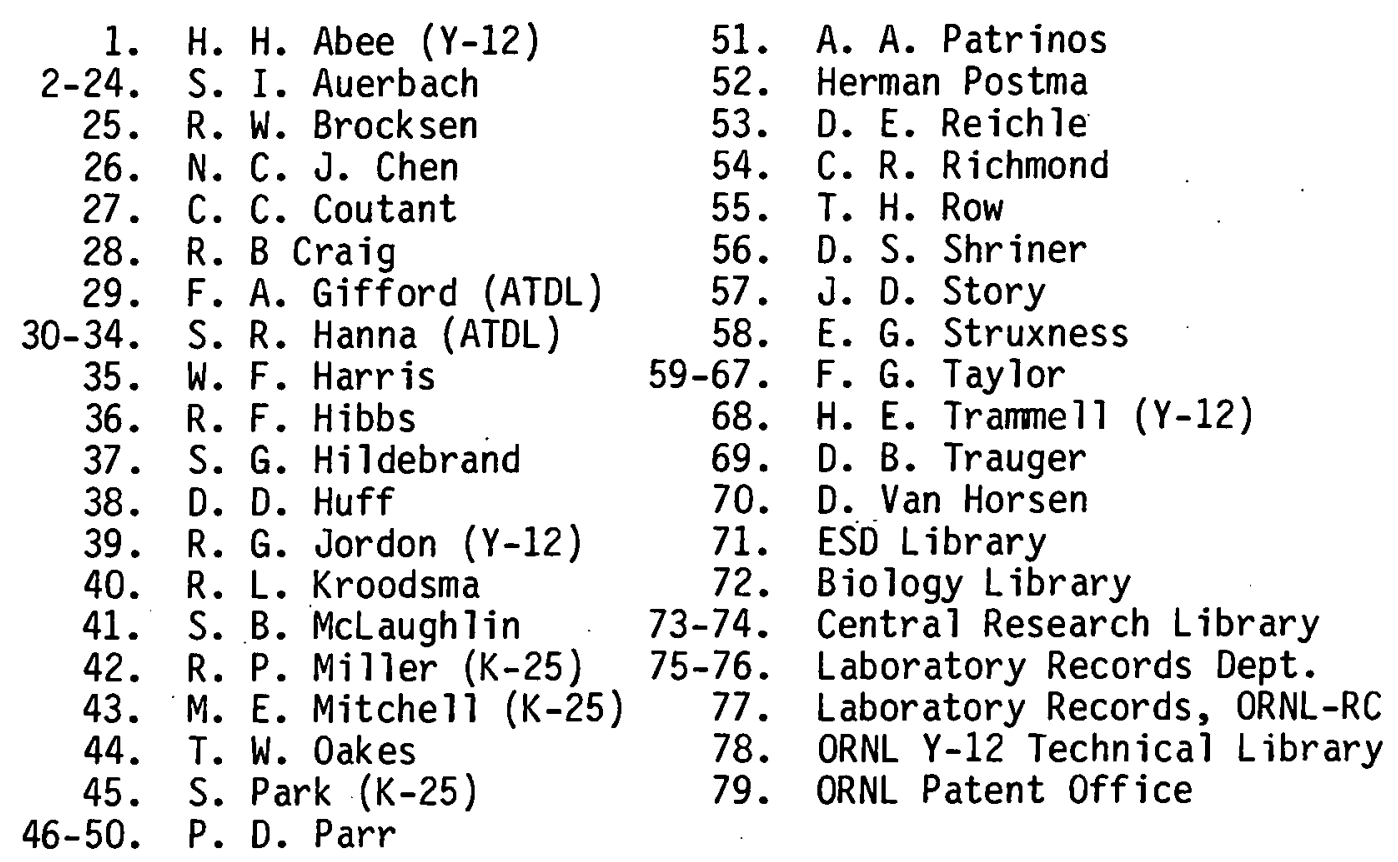

EXTERNAL DISTRIBUTION

80. Office of Assistant Manager, Energy Research and Development, DOE-ORO

81. D. L. Ashburn, Technical Services Division, Union Carbide Corporation-Nuclear Division, Paducah Gaseous Diffusion Plant, P.0. Box 1410, Paducah, KY 42001

82. R. C. Baker, Technical Services Division, Union Carbide Corporation-Nuclear Division, Paducah Gaseous Diffusion Plant, P.0. Box 1410, Paducah, KY 42001

83. James E. Carson, Environmental Statements Project, Argonne National Laboratory, Argonne, IL 60439

84. M. Clark Conrad, Technical Services Division, Union Carbide Corporation-Nuclear Division, Paducah Gaseous Diffusion Plant, P.0. Box 1410, Paducah, KY 42001

85. C. R. Curtis, Department of Plant Sciences, University of Delaware, Newark, DE 19711

86. R. C. Dahiman, Office of Environmental Research, U.S. Department of Energy, Washington, DC 20545

87. Virgil Emler, General Safety and Environmental Management, Goodyear Atomic Corporation, P.0. Box 628, Piketon, $\mathrm{OH}$ 45661

88. W. A. Feder, Suburban Experiment Station, University of Massachusetts, 240 Beaver St., Waltham, MA 02154

89. Ralph Frank 7in, Environmental Branch, Office of Environmental Research, U.S. Department of Energy, Washington, DC 20545 
90. D. Heyward Hamilton, Environmental Branch, Office of Environmental Research, U.S. Department of Energy, Washington, DC 20545

91. Peter House, Office of Technology Impacts, U.S. Department of Energy, Washington, DC 20545

92. J. S. Jacobson, Center for Environmental Research, Corne 11 University, 468 Hollister Hall, Ithaca, NY 14853

93. H. C. Jones, Air Quality Branch, Tennessee Valley Authority, Muscle Shoals, AL 37660

94. W. T. Lawhon, Manager, Ecology and Ecosystems Analys is Section, Battelle Columbus Laboratories, 505 King Ave., Co.Jumbus, $\mathrm{OH} 432301$

95. Dave Netzer, Environmental Protection, Goodyear Atomic Corporation, P.0. Box 628, Piketon, $\mathrm{OH} 45661$

96. Paducah P.lant Library, Union Carbide Corporation-Nuclear Division, Paducah Gaseous Diffusion Plant, P.0. Box 1410, Paducah, KY 42001

97. David Slade, Office of Environmental Research, U.S. Department of Energy, Washington, DC 20545

98. Jeff Swinebroad, Manager, Environmental Programs, Office of Environmental, Research, U.S. Department of Energy, Washington, DC 20545

99. R. L. Watters, Environmental Branch, Office of Environmental Research, U.S. Department of Energy, Washington, DC 20545

100. R. Bruce Wrinkle, Technical Services Division, Union Carbide Corporation-NuClear Division, Paducah Gaseous Diffusion Plant, Paducah, KY 42001

101-127. Technical Information Center, Oak Ridge, TN 37830 